Selcuk Journal of Agriculture and Food Sciences

http://sjafs.selcuk.edu.tr/sjafs/index

Research Article
SJAFS

(2020) 34 (3), 214-222

e-ISSN: $2458-8377$

DOI:10.15316/SJAFS.2020.219

\title{
Sesamum indicum and Trichilia heudelotii N-hexane and Ethanol Extracts: Ef- fective Remedy Against Callosobruchus maculates F. (Coleoptera: Chrysomeli- dae) Infesting Cowpea Grains
}

\author{
(D) Temitope Olawale ILESANMI ${ }^{1}$, (D) Victoria Gbonjubola AWOLOLA ${ }^{2}$, (DOmotayo Robert UDDIN II $^{1}$, \\ DS Suleiman MUSTAPHA ${ }^{1}$, (D) Temidayo Mujidat LAWAL ${ }^{1}$ \\ ${ }^{1}$ Department of Crop Protection, University of Ilorin, Ilorin, Nigeria \\ ${ }^{2}$ Department of Industrial Chemistry, University of Ilorin, Ilorin, Nigeria
}

\begin{tabular}{l}
\hline ARTICLE INFO \\
\hline Article history: \\
Received date: 07.06 .2020 \\
Accepted date: 10.11 .2020 \\
\hline Edited by: \\
Murat KARACA; Selcuk University, \\
Turkey \\
\hline
\end{tabular}

Keywords:

Pest Control

Callosobruchus Maculatus

Cowpea Grains

Plant Extracts

Phytochemical

Botanicals

\begin{abstract}
ABSRACT
The use of synthetic pesticidesusage to prevent cowpea weevils have been reported to be harmful, sometimes leading to the demise of consumersby ingestion of contaminated grains. To save lives, efforts are intensely made to seek after safer alternatives one in particular, is the use of plant based biopesticides. A study was conducted to investigate the effectiveness of $\mathrm{N}$ hexane and ethanol extracts of both sesame (Sesamum indicum) leaf and seed and;Trichilia heudelotii leaf to control Callosobruchus maculatusinfesting grains of cowpea. The methods employed involved dressing cowpea seeds (100 g) with the botanical crudeextracts at 0 (control), $0.5,1.0$ and $1.5 \mathrm{ml}$ respectively. Next, six pairs of newly emerged adult $C$. maculatus were introduced into glass vials containing treated seeds in three replicatesand observation was conducted for; adult mortality; emergence of larvae, pupae, and new adults of the insect;weight loss of cowpea grains; and qualitative phytochemical screening. The results presented in this paper revealed that the N-hexane and ethanol extracts of both sesame and $T$. heudelotii were significantly $(\mathrm{p}<0.05)$ effective mostly at $1.5 \mathrm{ml}$ in controlling the weevil when compared to the control. The phytochemical analysis indicated the presence of some useful bioactive compounds in the extracts. The observation on weight loss of cowpea revealed that all the various treatment especially at 1.5 $\mathrm{ml}$ sustained a significant $(\mathrm{p}<0.05)$ weight compared to the control $($ mean $=$ 40.00) which was lower. A plausible usage of homemade biopesticide using sesame and $T$. heudelotii could be suggested as additives to cowpea grains in the control of $C$. maculatus.
\end{abstract}

\section{Introduction}

Cowpea (Vigna unguiculata L. Walp) is cultivated for its nutritious grains, leaves, and green pods, which plays an important part in the protein requirement for both rural and urban settlers and also a source of quality fodder for livestock and provide cash inflow to the buyers and sellers of the crop (Wakili, 2013; Langyintuo\&Lowenberg, 2006). The protein content of cowpea has been classed to be about $23 \%$ making it a desirable source of plant based protein (FAO, 2005). It is also rich in starch with seeds containing about $63.6 \%$ carbohydrate in them as reported by Akyaw et al. (2014). The production practices of growing cowpea

*Corresponding author email: juniorsuleiman78@gmail.com has been estimated to support over 850 million people worldwide showing that the importance of the crop should not be underestimated especially in supplying the nutrition requirements of the undernourished in sub-Saharan Africa (FAO, 2005). Up to $70 \%$ of the world's cowpea supplies come from the dry Savanna and Sahel Zones of West and Central Africa because the crop is relatively well adapted to the agricultural ecosystem of these areas (Timko et al., 2007; Coulibaly et al., 2009).

Despite the afore mentioned benefits and importance of cowpea, the production yield is still considered to be very low at 100 to $500 \mathrm{~kg} \mathrm{ha}^{-1}$ in farming conditions compared to the potential yield of 1.5 to 3 tons ha ${ }^{-1}$ (Rachie, 1985; Karungi et al., 2000; Asante et al. 2001; Asiwe et al., 2009; Boukar\&Fatokun, 2009; Oyewale\&Bamaiyi, 2013; 
Singh, 2014). This low yield has been attributed to a combination of both abiotic and biotic stress factors most especially insect pests' infestations and damage having the most negative influence on the production of cowpea,sometimes depleting the average grain yields to up to 90 to $80 \%$ under intense infestations (Togola et al., 2017; Singh, 2014; Jackai\&Daoust, 1986; Singh \&Jackai, 1985).

One of the known most prominent and important insect pest of this crop is the field-to-store cowpea weevil- Callosobruchus maculatus (Fabricius)which belong to the Order Coleoptera and Family Chrysomelidae(Brisibeet al.,2011). When cowpea are allowed to wait in the field for longer periods before harvest, the greater the damage to cowpea grains in storage that will be incurred by the insect pest sometimes reaching a $50 \%$ damage level within the space of few months in storage (Dugie et al., 2009). The larvae of the bruchid weevil depends on the grains for its nutrition, feeding and developing exclusively on it. Adult weevils emerge from cowpea grains leaving exit holes. Substantial infestation rates causes loss of quality and the growth of mould invariably reducing market quality and loss of farmers income (Mulatu\& Gebremedhin, 2000). Enormous losses of about 50 to $100 \%$ have been recorded on stored cowpea due to attack by C. maculatus (Udo \& Harry, 2013).

The use of chemical insecticides remains the commonest measure used so far to control ofthe insect pest. However, the practice is extremely hazardous to users and consumers (Togola et al., 2017) sometimes leading to death of consumers as in the case of people who died in Nigeria after consuming beans containing high levels of pesticides used in preventing the bruchid weevils from attacking cowpea grains. This event was later known as the killer beans spree (Shiabu, 2008; Gwary et al., 2012) thereby prompting both farmers and consumers with the urgent need to search for safer alternatives to chemical insecticides. Efforts are being made to seek eco-friendly alternative including the use of biopesticides (Togola et al., 2017) hence the reason for conducting this investigation. The current study's objective is to investigate the use of plant materials namely Sesamum indicum L (Pedaliaceae: Lamiales) and Trichilia heudelotii Planch (Meliaceae: Sapindales) as a biopesticide alternative to the use of chemical insecticidesin the control of Callosobruchus maculatus affecting cowpea grains. These plants are easily sourced within sub-Saharan Africa where major cowpea production yield have been reportedand have also been observed to grow as part of natural vegetation in the region, thereby the above mentioned plants as biopesticidewas investigated to study their effectiveness against the bruchid beetle.

\section{Materials and Methods}

\subsection{Culture of Callosobruchus maculatus}

Mass culture of $C$. maculatus was maintained using the procedure described by Strong et al. (1968).The variety of cowpea used for this experiment was the variety IT96D-610 provided by the International Institute of Tropical Agriculture (IITA), Ibadan, Nigeria. Seeds were described to be susceptible to attacksand infestation by the insect pest Callosobruchus maculatus. The insects were acquired from stock cultures from the Nigerian Stored Products Research Institute (NISPRI), Ilorin, Nigeria. Six pairs of 0-1 day-old adults (male and female) of C. maculatus were isolated and introduced into small glass vials $(7.5 \times 2.5 \mathrm{~cm})$ containing untreated cowpea seeds (Khalequzzaman et al., 2007). The insects were given 7 days to mate and oviposit in the cowpea. Glass vials were covered with muslin cloth and secured firmly with rubber bands to prevent escape of the insect.After one week, when oviposition had been noticed, the parent stocks of $C$. maculatus were removed and vials were left under laboratory conditions (temperature 24$28^{\circ} \mathrm{C}$, relative humidity of $70 \%$ ) till the emergence of new filial progenies which were used for the experiment.

\subsection{Sample preparations and extraction}

Sample preparation and extraction was done according to the methods described by Uddin II et al (2020). The plant materials, Sesamum indicumseeds and leaves and,Trichilia heudelotii leaves were airdried at room temperature, turning regularly to ensure even and thorough drying to avoid moulding of the samples. The dried plant materials were ground using an electric grinder and sieved using a 90-micron mesh sieve to obtain fine powder of the samples. The powdered leaves $(650 \mathrm{~g}$ for Trichilia heudelotii and $700 \mathrm{~g}$ for Sesamum indicum) and seeds $(1.1 \mathrm{~kg})$ were extracted twice by maceration, sequentially with a nonpolar and polar organic solvents, hexane (Hex) and ethanol $(\mathrm{EtOH})$ respectively. Yields of $14.26 \mathrm{~g}(\mathrm{Hex})$ and $10.24 \mathrm{~g}(\mathrm{EtOH})$ of Trichilia heudelotiileaves and $12.24 \mathrm{~g}$ (Hex) and $13.04 \mathrm{~g}(\mathrm{EtOH})$ of Sesamum indicumwas obtained after evaporation of the organic solvents. For the sesame seeds, $8.6 \mathrm{~g}$ (Hex) and $12.8 \mathrm{~g}$ $(\mathrm{EtOH})$ was obtained. The crude extracts obtained used for the experiment were then prepared using an aqueous solution of $1 \% \mathrm{v} / \mathrm{v}$ of acetic acid in distilled water and concentrated at $0.5 \mathrm{~g}$ per $\mathrm{ml}$. 


\subsection{Phytochemical screening (qualitative)}

Chemical tests were carried out on both the ethanolic and $\mathrm{N}$-Hexane extracts for the qualitative determination of phytochemical constituents as described by Harborne (1973), Trease and Evans (1989) and Sofowora (1993).

Test for Tannins:Few drops of $1 \%$ lead acetate was added to $0.2 \mathrm{~g}$ of the extract and observed for the formation of yellow precipitate

Test for Alkaloids:Exactly $0.2 \mathrm{~g}$ of the extract was stirred with $5 \mathrm{ml}$ of $1 \%$ aqueous $\mathrm{HCl}$ on water bath and then filtered. One $\mathrm{ml}$ of the filtrate was taken individually into two separate test tubes. To the first portion, Mayer's reagent was added and appearance of buffcoloured precipitate was an indication for the presence of alkaloids. To the second portion, few drops of Dragendorff's reagent was added to the filtrate and observed for the formation of an orange-red precipitate.

Test for Terpenoids: Exactly $2 \mathrm{ml}$ of chloroform was added to $0.2 \mathrm{~g}$ of the extract, $3 \mathrm{ml}$ of concentrated sulphuric acid was added carefully to form a layer. Formation of a reddish-brown colouration at the interface indicates the presence of terpenoids.

Test for Phenolic Compounds: The extract $(0.5 \mathrm{~g})$ was dissolved in $5 \mathrm{ml}$ of distilled water. To this, few drops of neutral $5 \%$ ferric chloride solution was added. A dark green colour indicates the presence of phenolic compounds.

Test for Flavonoids:Exactly $4 \mathrm{ml}$ of dilute ammonia solution was added to a portion of the extract followed by addition of concentrated sulphuric acid. A yellow colouration indicates the presence of flavonoids.

Test for Saponins:Exactly $1 \mathrm{~g}$ of the extract was boiled with $5 \mathrm{ml}$ of distilled water and filtered. To the filtrate, about $3 \mathrm{ml}$ of distilled water was further added and shaken vigorously for about 5 minutes. Frothing which persists on warming shows the presence of saponins.

Test for Steroids:Acetic anhydride $(2 \mathrm{ml})$ was added to a portion of the extract with $2 \mathrm{ml} \mathrm{H}_{2} \mathrm{SO}_{4}$. Colour change from violet to blue or green indicates the presence of steroids.

\subsection{Experimental procedure}

The experiment was carried out under ambient laboratory conditions. One hundred gram (100 g) of undamaged cowpea were placed in glass vials $(7.5 \times$ $2.5 \mathrm{~cm}$ ). The seeds were properly mixed with the various levels of the botanical treatment extracts at 0.5, 1.0, and $1.5 \mathrm{ml}$ respectively using a wooden spatula to ensure uniform coating of the seeds. The control $(0.0$ ml) had no treatment applied to it. Six pairs of newly emerged male and female adult $C$. maculatus were introduced after drying coated seeds for five minutes and glass vials were ensured covered with muslin cloth fastened with rubber bands to permit ventilation and prevent escape of the insect. The experiment was a Completely Randomized Design (CRD) with three replications. Dead beetles were removed from vials every 24 hours interval when beetles were noticed to be inactive and unresponsive to probing of the abdomen using an entomological needle (Uddin et al., 2020).

Oviposition rate was recorded at day 7 after treatment (DAT) and ten seeds were randomly selected from each treatment vials to view eggs laid using $\mathrm{a} \times$ 100 magnifying lens. Larval and pupae emergence was recorded at 15 and 23 DAT respectively by also selecting 10 seeds at random from the various treatments and control and dissecting seeds gently with a sharp razor blade to check for the presence of $C$. maculatus larvae and pupae in cowpea seeds. Emergence of adult progeny was recorded from 33 days after treatment and the adults removed every 24 hours to avoid the next generationThe percentage loss in cowpea grain weight was recorded at day 38 after release of beetles that have completely emerged (Khalequzzaman et al., 2007). Data collected were subjected to a two-way analysis of variance and T-test and significant mean differences were separated using New Duncan Multiple Range Test set at a P-value of 0.05 .

\section{Results and Discussion}

\subsection{Effects of the selectedextracts on adult mortality of Callosobruchus maculatus after treatment}

The experiment showed significant results between the various botanical extracts and the control. Post hoc analysis revealed that at $1 \mathrm{DAT}$, both the N-Hexane extract and the ethanol extract of sesame leaf were the most effective treatment, significantly $(\mathrm{p}<0.05)$ able to suppress the population of $C$. maculatus by the mean number of 6.00 in both treatment at the concentration rate of $1.5 \mathrm{ml}$ when compared to the other treatment and the control (Table 1). Further observation also indicated that the next effective botanical treatment were the N-Hexane and Ethanol extract of T. heudelotii leaf which were also significantly $(\mathrm{p}<0.05)$ able to suppress the insect pest adult population to a mean number of 5.33 at the increasing concentration rate of $1.5 \mathrm{ml}$ when compared to the control $(0.0 \mathrm{ml})$ which had a mortality rate of 2.33 as shown in Table 1 . The highest mortality was recorded to occur within 24 hour period after treatment (Table 1). 
Ilesanmi et al. / Selcuk J Agr Food Sci, (2020) 34 (3), 214-222

Table1

Comparative effect of the botanical treatment extracts on adult mortality of Callosobruchus maculatus

\begin{tabular}{|c|c|c|c|c|c|c|}
\hline \multicolumn{7}{|c|}{$\begin{array}{l}\text { Adult Mortality } \\
\text { Days after treatment (DAT) }\end{array}$} \\
\hline Treatments & Conc.(ml) & 1 & 2 & 3 & 4 & 5 \\
\hline \multirow[t]{3}{*}{ NHTL } & 0.5 & $4.00^{\mathrm{abcd}} \pm 1.00$ & $1.67^{\mathrm{abc}} \pm 0.58$ & $1.67^{\mathrm{ab}} \pm 0.58$ & $0.67^{\mathrm{abc}} \pm 0.58$ & $0.00^{\mathrm{a}} \pm 0.00$ \\
\hline & 1.0 & $5.00^{\mathrm{bcd}} \pm 0.00$ & $1.33^{\mathrm{abc}} \pm 0.58$ & $1.00^{\mathrm{ab}} \pm 0.00$ & $0.67^{\mathrm{abc}} \pm 0.58$ & $0.00^{\mathrm{a}} \pm 0.00$ \\
\hline & 1.5 & $5.33^{\mathrm{cd}} \pm 1.53$ & $1.67^{\mathrm{abc}} \pm 0.58$ & $1.00^{\mathrm{ab}} \pm 0.00$ & $0.00 \pm 0.000^{\mathrm{a}}$ & $0.00^{\mathrm{a}} \pm 0.00$ \\
\hline \multirow{3}{*}{ NHSS } & 0.5 & $4.00^{\mathrm{abcd}} \pm 1.00$ & $1.33^{\mathrm{abc}} \pm 0.58$ & $1.33^{\mathrm{ab}} \pm 0.58$ & $1.33^{\mathrm{bc}} \pm 0.58$ & $0.00^{\mathrm{a}} \pm 0.00$ \\
\hline & 1.0 & $4.67^{\mathrm{abcd}} \pm 0.58$ & $1.33^{\mathrm{abc}} \pm 0.58$ & $1.00^{\mathrm{ab}} \pm 0.00$ & $0.67^{\mathrm{abc}} \pm 0.58$ & $0.33^{\mathrm{a}} \pm 0.58$ \\
\hline & 1.5 & $5.00^{\mathrm{bcd}} \pm 0.00$ & $2.00^{\mathrm{abc}} \pm 1.00$ & $0.67^{\mathrm{a}} \pm 1.16$ & $0.33^{\mathrm{ab}} \pm 0.58$ & $0.00^{\mathrm{a}} \pm 0.00$ \\
\hline \multirow[t]{3}{*}{ NHSL } & 0.5 & $4.33^{\mathrm{abcd}} \pm 1.52$ & $1.33^{\mathrm{abc}} \pm 1.16$ & $1.00^{\mathrm{ab}} \pm 0.00$ & $1.00^{\mathrm{abc}} \pm 0.00$ & $0.33^{\mathrm{a}} \pm 0.58$ \\
\hline & 1.0 & $5.00^{\mathrm{bcd}} \pm 0.00$ & $1.67^{\mathrm{abc}} \pm 0.58$ & $0.67^{\mathrm{a}} \pm 1.16$ & $0.67^{\mathrm{abc}} \pm 0.58$ & $0.00^{\mathrm{a}} \pm 0.00$ \\
\hline & 1.5 & $6.00^{\mathrm{d}} \pm 1.00$ & $1.00^{\mathrm{ab}} \pm 0.00$ & $1.00^{\mathrm{ab}} \pm 0.00$ & $0.00^{\mathrm{a}} \pm 0.00$ & $0.00^{\mathrm{a}} \pm 0.00$ \\
\hline \multirow[t]{3}{*}{ ETHTL } & 0.5 & $4.67^{\mathrm{abcd}} \pm 1.16$ & $1.67^{\mathrm{abc}} \pm 0.58$ & $0.67^{\mathrm{a}} \pm 1.16$ & $0.67^{\mathrm{abc}} \pm 0.58$ & $0.33^{\mathrm{a}} \pm 0.58$ \\
\hline & 1.0 & $5.33^{\mathrm{cd}} \pm 1.53$ & $1.00^{\mathrm{ab}} \pm 1.00$ & $0.67^{\mathrm{a}} \pm 1.16$ & $0.33^{\mathrm{ab}} \pm 0.58$ & $0.67^{\mathrm{a}} \pm 0.58$ \\
\hline & 1.5 & $5.33^{\mathrm{cd}} \pm 1.53$ & $0.67^{\mathrm{a}} \pm 0.578$ & $1.33^{\mathrm{ab}} \pm 0.58$ & $0.67^{\mathrm{abc}} \pm 0.58$ & $0.00^{\mathrm{a}} \pm 0.00$ \\
\hline \multirow{3}{*}{ ETHSS } & 0.5 & $4.00^{\mathrm{abcd}} \pm 1.00$ & $1.00^{\mathrm{ab}} \pm 0.00$ & $1.33^{\mathrm{ab}} \pm 0.58$ & $1.00^{\mathrm{abc}} \pm 0.00$ & $0.67^{\mathrm{a}} \pm 0.58$ \\
\hline & 1.0 & $3.67^{\mathrm{abcd}} \pm 1.53$ & $1.33^{\mathrm{abc}} \pm 1.16$ & $2.00^{\mathrm{ab}} \pm 1.00$ & $0.67^{\mathrm{abc}} \pm 0.58$ & $0.33^{\mathrm{a}} \pm 0.58$ \\
\hline & 1.5 & $3.33^{\mathrm{abc}} \pm 0.58$ & $1.67^{\mathrm{abc}} \pm 0.58$ & $2.33^{\mathrm{b}} \pm 1.155$ & $0.67^{\mathrm{abc}} \pm 0.58$ & $0.00^{\mathrm{a}} \pm 0.00$ \\
\hline \multirow[t]{3}{*}{ ETHSL } & 0.5 & $4.00^{\mathrm{abcd}} \pm 1.00$ & $1.67^{\mathrm{abc}} \pm 0.58$ & $1.67^{\mathrm{ab}} \pm 0.58$ & $0.33^{\mathrm{ab}} \pm 0.58$ & $0.33^{\mathrm{a}} \pm 0.58$ \\
\hline & 1.0 & $4.67^{\mathrm{abcd}} \pm 1.53$ & $1.67^{\mathrm{abc}} \pm 1.16$ & $1.33^{\mathrm{ab}} \pm 0.58$ & $0.33^{\mathrm{ab}} \pm 0.58$ & $0.00^{\mathrm{a}} \pm 0.00$ \\
\hline & 1.5 & $6.00^{\mathrm{d}} \pm 1.00$ & $0.67^{\mathrm{a}} \pm 0.58$ & $1.33^{\mathrm{ab}} \pm 0.58$ & $0.00^{\mathrm{a}} \pm .00$ & $0.00^{\mathrm{a}} \pm 0.00$ \\
\hline Control & 0.0 & $2.33^{\mathrm{a}} \pm 1.53$ & $1.00^{\mathrm{ab}} \pm 0.00$ & $1.00^{\mathrm{ab}} \pm 0.00$ & $1.67^{\mathrm{c}} \pm 0.58$ & $2.00^{\mathrm{b}} \pm 1.73$ \\
\hline
\end{tabular}

Means followed by the same letter (s) in a column are not significantly different from each other at $\mathrm{P}<0.05$ according to New Duncan's Multiple Range Test

Keys: Conc. $=$ Concentration, NHTL $=$ N-Hexane extract of $T$. heudelotii leaf, NHSS $=$ N-Hexane extract of sesame seed, NHSL $=$ N-Hexane extract of sesame leaf, ETHTL $=$ Ethanol extract of $T$ heudelotii leaf, ETHSS $=$ Ethanol extract of sesame seed, ETHSL = Ethanol extract of sesame leaf

\subsection{Effects of the selectedextracts on the mean number of eggs, larvae emergence and pupaeofC. maculatus after treatment}

There were significant $(\mathrm{p}<0.05)$ differences between the treatments and the control. Table 2 showed that all the various treatments were effective in restricting the amount of eggs laid by $C$. maculatusalthough, the N-Hexane extract of sesame leaf was observed to have the least mean number of eggs laid by the insect pest (1.33) at the concentration level of 1.5 mlwhen compared to the others (Table 2). The control did not show any reduction in the egg laying activities of the insect and as such had the highest rate of oviposition (8.33) as shown in Table 2.

Table 2 also showed that all the various treatments were significantly effective in restricting the larvae emergence of $C$. maculatus at different concentration levels, although the concentration rate of the botanical extracts: N-Hexane T. heudelotii leaf, N-Hexane sesame seed, N-Hexane sesame leaf, Ethanol $T$. heudelotii leaf and Ethanol sesame seed at $1.5 \mathrm{ml}$ was observed to have the lowest mean number (1.00) of emerged larvaeof the insect pest (Table 2). The control had the highest mean number (6.00) of larvae that emerged and thus was significantly $(p<0.05)$ higher when compared to the botanical treatments which were able to suppress the numbers of emerging larvae of the weevil as seen in Table 2.

On the amount of $C$. maculatus pupae recorded after treatment, the experiment showed significant results between the various treatment extracts and the control. It was observed that the botanical extracts used were effective in suppressing the numbers of $C$. maculatus pupating (Table 2). Close observation of the mean numbers of pupae seen further indicated that the ethanol extract of $T$. heudelotii leaf at the concentration rates of 1.0 and $1.5 \mathrm{ml}$ had the least amount of pupae at the mean number of $0.67( \pm 0.58)$ each. This was also the same for the ethanol extract of sesame seed at 1.5 $\mathrm{ml}(0.67 \pm 0.58)$. The control $(4.67 \pm 0.58)$ had the most amount of pupae seen in the experiment when compared to the treated ones shown in Table 2. 
Table 2

Effect of the different treatments on the mean numbers of eggs, larvae emergence and pupae of $C$. maculatus

\begin{tabular}{lllll}
\hline & & 7 DAT & 15 DAT & 23 DAT \\
\hline Treatments & Conc. $(\mathrm{ml})$ & Eggs laid & Larvae emergence & Pupae \\
NHTL & 0.5 & $4.00^{\mathrm{abcd}} \pm 1.00$ & $2.00^{\mathrm{abc}} \pm 1.00$ & $1.67^{\mathrm{abc}} \pm 0.58$ \\
& 1.0 & $3.67^{\mathrm{abcd}} \pm 1.53$ & $1.33^{\mathrm{ab}} \pm 0.58$ & $1.00^{\mathrm{ab}} \pm 0.00$ \\
NHSS & 1.5 & $3.33^{\mathrm{abcd}} \pm 1.53$ & $1.00^{\mathrm{a}} \pm 0.00$ & $1.00^{\mathrm{ab}} \pm 0.00$ \\
& 0.5 & $3.67^{\mathrm{abcd}} \pm 1.53$ & $1.67^{\mathrm{abc}} \pm 0.58$ & $1.67^{\mathrm{abc}} \pm 0.58$ \\
NHSL & 1.0 & $3.33^{\mathrm{abcd}} \pm 1.16$ & $1.67^{\mathrm{abc}} \pm 0.58$ & $1.33^{\mathrm{abc}} \pm 0.58$ \\
& 1.5 & $2.00^{\mathrm{abc}} \pm 0.00$ & $1.00^{\mathrm{a}} \pm 0.00$ & $1.00^{\mathrm{ab}} \pm 0.00$ \\
ETHTL & 0.5 & $2.67^{\mathrm{abcd}} \pm 1.53$ & $1.33^{\mathrm{ab}} \pm 0.58$ & $1.33^{\mathrm{abc}} \pm 0.58$ \\
& 1.0 & $1.67^{\mathrm{ab}} \pm 1.16$ & $1.33^{\mathrm{ab}} \pm 0.58$ & $1.00^{\mathrm{ab}} \pm 0.00$ \\
ETHSS & 1.5 & $1.33^{\mathrm{a}} \pm 0.58$ & $1.00^{\mathrm{a}} \pm 0.00$ & $1.00^{\mathrm{ab}} \pm 0.00$ \\
& 0.5 & $4.00^{\mathrm{abcd}} \pm 1.00$ & $1.67^{\mathrm{abc}} \pm 0.58$ & $1.33^{\mathrm{abc}} \pm 0.58$ \\
ETHSL & 1.0 & $3.33^{\mathrm{abcd}} \pm 1.16$ & $1.33^{\mathrm{ab}} \pm 0.58$ & $0.67^{\mathrm{a}} \pm 0.58$ \\
& 1.5 & $3.00^{\mathrm{abcd}} \pm 1.00$ & $1.00^{\mathrm{a}} \pm 0.00$ & $0.67^{\mathrm{a}} \pm 0.58$ \\
& 0.5 & $4.33^{\mathrm{bcd}} \pm 0.58$ & $1.67^{\mathrm{abc}} \pm 0.58$ & $2.00^{\mathrm{abc}} \pm 0.00$ \\
Control & 1.0 & $2.67^{\mathrm{abcd}} \pm 1.16$ & $1.67^{\mathrm{abc}} \pm 0.58$ & $1.67^{\mathrm{abc}} \pm 1.16$ \\
\hline
\end{tabular}

Means followed by the same letter (s) in a column are not significantly different from each other at $\mathrm{P}<0.05$ according to New Duncan's Multiple Range Test,

Keys:DAT $=$ day after treatment, Conc. $=$ Concentration, NHTL $=$ N-Hexane extract of $T$. heudelotii leaf, NHSS $=$ NHexane extract of sesame seed, NHSL $=$ N-Hexane extract of sesame leaf, ETHTL = Ethanol extract of Theudelotii leaf, ETHSS = Ethanol extract of sesame seed, ETHSL = Ethanol extract of sesame leaf

\subsection{Effects of the selectedextracts on the mean number} of newly emerged C. maculatus adults

Table 3 showed the effects of the different botanical treatments against the emergences of $C$. maculatusadults. All of the treatment extracts were effective in restricting the emergence of the adults and were thus significantly $(\mathrm{p}<0.05)$ potent when compared to the control which had the highest population of newly emerged $C$. maculatus adultsfrom 33 to 37 DAT with the mean numbers of $2.67( \pm 1.16), 3.00( \pm 1.73)$, $2.67( \pm 1.16), 3.00( \pm 1.00)$ and $2.33( \pm 0.58)$ respectively. Consideration of the mean numbers of the treatments indicated that N-Hexane sesame leaf $(0.0 \pm 0.00)$ and Ethanol sesame leaf extract $(0.0 \pm 0.00)$ at $1.5 \mathrm{ml}$ had no emergence of $C$. maculatus adults recorded at 33 DAT (Table3).

Table 3

Effect of treatments on the number of newly emerged $C$. maculatus adults

\begin{tabular}{lllllll}
\hline & & \multicolumn{5}{c}{ Days after treatment (DAT) } \\
\hline Treatment & Conc. $(\mathrm{ml})$ & 33 & 34 & 35 & 36 & 37 \\
NHTL & 0.5 & $0.67^{\mathrm{abc}} \pm 0.58$ & $1.00^{\mathrm{ab}} \pm 1.00$ & $1.67^{\mathrm{abc}} \pm 0.58$ & $1.33^{\mathrm{ab}} \pm 1.16$ & $1.33^{\mathrm{bcde}} \pm 0.58$ \\
& 1.0 & $1.33^{\mathrm{abcd}} \pm 0.58$ & $1.33^{\mathrm{ab}} \pm 0.58$ & $1.00^{\mathrm{ab}} \pm 0.00$ & $1.00^{\mathrm{ab}} \pm 1.00$ & $0.67^{\mathrm{abc}} \pm 0.58$ \\
& 1.5 & $1.00^{\mathrm{abc}} \pm 1.00$ & $0.67^{\mathrm{ab}} \pm 0.58$ & $1.33^{\mathrm{abc}} \pm 0.58$ & $0.67^{\mathrm{ab}} \pm 0.58$ & $0.33^{\mathrm{ab}} \pm 0.58$ \\
NHSS & 0.5 & $0.67^{\mathrm{abc}} \pm 0.58$ & $1.00^{\mathrm{ab}} \pm 1.00$ & $0.67^{\mathrm{ab}} \pm 0.58$ & $0.33^{\mathrm{ab}} \pm 0.58$ & $1.00^{\mathrm{abc}} \pm 0.00$ \\
& 1.0 & $0.67^{\mathrm{abc}} \pm 0.58$ & $0.67^{\mathrm{ab}} \pm 1.16$ & $1.00^{\mathrm{ab}} \pm 0.00$ & $0.33^{\mathrm{ab}} \pm 0.58$ & $0.33^{\mathrm{ab}} \pm 0.58$ \\
NHSL & 1.5 & $0.33^{\mathrm{ab}} \pm 0.58$ & $1.00^{\mathrm{ab}} \pm 1.00$ & $0.33^{\mathrm{a}} \pm 0.577$ & $0.67^{\mathrm{ab}} \pm 0.58$ & $0.33^{\mathrm{ab}} \pm 0.58$ \\
& 0.5 & $0.33^{\mathrm{ab}} \pm 0.58$ & $0.67^{\mathrm{ab}} \pm 0.58$ & $1.33^{\mathrm{abc}} \pm 0.58$ & $1.00^{\mathrm{ab}} \pm 1.00$ & $0.33^{\mathrm{ab}} \pm 0.58$ \\
ETHTL & 1.0 & $0.67^{\mathrm{abc}} \pm 0.58$ & $0.33^{\mathrm{a}} \pm 0.58$ & $0.67^{\mathrm{ab}} \pm 0.58$ & $0.00^{\mathrm{a}} \pm 0.00$ & $0.33^{\mathrm{ab}} \pm 0.58$ \\
& 1.5 & $0.00^{\mathrm{a}} \pm 0.00$ & $0.33^{\mathrm{a}} \pm 0.58$ & $0.67^{\mathrm{ab}} \pm 0.58$ & $0.33^{\mathrm{ab}} \pm 0.58$ & $0.00^{\mathrm{a}} \pm 0.00$ \\
& 0.5 & $0.67^{\mathrm{abc}} \pm 0.58$ & $1.00^{\mathrm{ab}} \pm 1.00$ & $1.33^{\mathrm{abc}} \pm 0.58$ & $1.00^{\mathrm{ab}} \pm 1.00$ & $1.00^{\mathrm{abcd}} \pm 1.00$ \\
& 1.0 & $1.00^{\mathrm{abc}} \pm 1.00$ & $1.00^{\mathrm{ab}} \pm 1.00$ & $1.00^{\mathrm{ab}} \pm 0.00$ & $1.00^{\mathrm{ab}} \pm 1.00$ & $0.33^{\mathrm{ab}} \pm 0.58$ \\
& 1.5 & $0.67^{\mathrm{abc}} \pm 1.16$ & $0.67^{\mathrm{ab}} \pm 0.58$ & $0.67^{\mathrm{ab}} \pm 0.58$ & $0.67^{\mathrm{ab}} \pm 1.16$ & $0.33^{\mathrm{ab}} \pm 0.58$ \\
\hline
\end{tabular}


Table 3

Effect of treatments on the number of newly emerged $C$. maculatus adults

\begin{tabular}{cllllll}
\hline ETHSS & 0.5 & $0.67^{\mathrm{ab}} \pm 0.58$ & $1.00^{\mathrm{ab}} \pm 1.00$ & $0.67^{\mathrm{ab}} \pm 0.58$ & $0.33^{\mathrm{ab}} \pm 0.58$ & $0.67^{\mathrm{abc}} \pm 1.16$ \\
& 1.0 & $0.33^{\mathrm{ab}} \pm 0.58$ & $0.67^{\mathrm{ab}} \pm 1.16$ & $0.67^{\mathrm{ab}} \pm 0.58$ & $0.67^{\mathrm{ab}} \pm 0.58$ & $0.33^{\mathrm{ab}} \pm 0.58$ \\
& 1.5 & $0.33^{\mathrm{ab}} \pm 0.58$ & $0.67^{\mathrm{ab}} \pm 0.58$ & $0.33^{\mathrm{a}} \pm 0.577$ & $0.67^{\mathrm{ab}} \pm 0.58$ & $0.33^{\mathrm{ab}} \pm 0.58$ \\
ETHSL & 0.5 & $0.67^{\mathrm{ab}} \pm 1.16$ & $1.67^{\mathrm{abc}} \pm 1.53$ & $1.00^{\mathrm{ab}} \pm 0.00$ & $1.00^{\mathrm{ab}} \pm 1.00$ & $0.67^{\mathrm{abc}} \pm 0.58$ \\
& 1.0 & $0.33^{\mathrm{ab}} \pm 0.58$ & $1.00^{\mathrm{ab}} \pm 1.00$ & $0.67^{\mathrm{ab}} \pm 1.16$ & $1.00^{\mathrm{ab}} \pm 1.00$ & $0.67^{\mathrm{abc}} \pm 0.58$ \\
Control & 1.5 & $0.00^{\mathrm{a}} \pm 0.00$ & $0.33^{\mathrm{a}} \pm 0.58$ & $0.67^{\mathrm{ab}} \pm 1.16$ & $0.33^{\mathrm{ab}} \pm 0.58$ & $0.33^{\mathrm{ab}} \pm 0.58$ \\
\hline
\end{tabular}

Means followed by the same letter ( $\mathrm{s}$ ) in a column are not significantly different from each other at $\mathrm{P}<0.05$ according to New Duncan's Multiple Range Test

Keys:Conc. $=$ Concentration, NHTL $=$ N-Hexane extract of $T$. heudelotii leaf, NHSS $=$ N-Hexane extract of sesame seed, NHSL $=$ N-Hexane extract of sesame leaf, ETHTL $=$ Ethanol extract of $T$ heudelotii leaf, ETHSS $=$ Ethanol extract of sesame seed, ETHSL $=$ Ethanol extract of sesame leaf

\subsection{Effects of the treatment extracts on the percentage weight of cowpea}

The experiment revealed that the various treatment sustained a significant amount of cowpea weight $(\mathrm{g})$ when compared to the control. However, the ethanol extract of sesame leaf retained the highest percentage weight of $93.33 \%$ of the cowpea at $1.5 \mathrm{ml}$ concentration followed by the ethanol extract of sesame seed $(86.67 \%)$, N-Hexane extract of sesame leaf $(86.66 \%)$ and N-Hexane extract of sesame seed $(86.66 \%)$ at 1.5 $\mathrm{ml}$ concentration when compared to the other botanical treatments and the control in Table 4. The control had a drastic loss of weight $(40.00 \%)$ significantly $(p<0.05)$ lower than the botanical treatments usedas shown in Table 4.

Table4

Effects of thetreatment extracts on the percentage weight of cowpea

\begin{tabular}{lll}
\hline Treatment & Conc. $(\mathrm{ml})$ & \% weight $(\mathrm{g})$ \\
\hline NHTL & 0.5 & $66.67^{\mathrm{bc}} \pm 6.67$ \\
& 1.0 & $73.33^{\mathrm{cd}} \pm 6.67$ \\
NHSS & 1.5 & $73.33^{\mathrm{cd}} \pm 6.67$ \\
& 0.5 & $66.67^{\mathrm{bc}} \pm 6.67$ \\
NHSL & 1.0 & $80.00^{\mathrm{de}} \pm 6.67$ \\
& 1.5 & $86.66^{\mathrm{e}} \pm 6.67$ \\
& 0.5 & $73.33^{\mathrm{cd}} \pm 0.00$ \\
ETHTL & 1.0 & $80.00^{\mathrm{de}} \pm 6.67$ \\
& 1.5 & $86.66^{\mathrm{ef}} \pm 6.67$ \\
ETHSS & 0.5 & $73.33^{\mathrm{cd}} \pm 6.67$ \\
& 1.0 & $73.33^{\mathrm{cd}} \pm 6.67$ \\
ETHSL & 0.5 & $73.33^{\mathrm{cd}} \pm 6.67$ \\
& 1.0 & $73.33^{\mathrm{cd}} \pm 6.67$ \\
& 1.5 & $86.66^{\mathrm{ef}} \pm 6.67$ \\
Control & 0.5 & $86.67^{\mathrm{ef}} \pm 6.65$ \\
\hline
\end{tabular}

Means followed by the same letter (s) in a column are not significantly different from each other at $\mathrm{P}<0.05$ according to New Duncan's Multiple Range Test
Keys:Conc. $=$ Concentration, NHTL $=$ N-Hexane extract of $T$. heudelotii leaf, NHSS $=\mathrm{N}-$ Hexane extract of sesame seed, NHSL $=$ N-Hexane extract of sesame leaf, ETHTL = Ethanol extract of $T$ heudelotii leaf, ETHSS $=$ Ethanol extract of sesame seed, ETHSL = Ethanol extract of sesame leaf

\subsection{Qualitative Phytochemical screening of the different botanical treatment extracts}

The qualitative phytochemical screening (Table 5) indicated that there was relatively moderate amount of alkaloid present in the N-hexane and ethanol sesame seedand in the N-hexane $T$. heudelotii extracts. Flavonoids were detected to be in trace amount in all the treatment extracts. Saponin was indicated to be moderately available in the ethanol sesame seed, and in the N-Hexane and ethanol T. heudelotii leaf. Tannin was mostly present in the ethanol sesame leaf extract with the other extracts having tannin in trace amount. Steroid was abundantly present in all the treatment extracts except in the ethanol sesame leaf and seed which were in moderate amount as shown in Table 5.

Table 5

Qualitative phytochemical analysis of the various treatment extracts

\begin{tabular}{lllllll}
\hline Phyto- & NH & ETH & NH & ETH & NH & ETH \\
chemicals & SL & SL & SS & SS & TL & TL \\
\hline Alkaloids & + & - & ++ & ++ & ++ & + \\
Flavonoids & + & + & + & + & + & + \\
Terpenoids & - & + & - & ++ & ++ & + \\
Saponin & + & + & + & ++ & ++ & ++ \\
Tannin & + & ++ & + & + & + & + \\
Steroid & +++ & ++ & +++ & ++ & +++ & ++ \\
\hline
\end{tabular}

Keys: NHTL $=$ N-Hexane extract of $T$. heudelotii leaf, NHSS $=$ N-Hexane extract of sesame seed, NHSL $=$ NHexane extract of sesame leaf, ETHTL = Ethanol extract of Theudelotii leaf, ETHSS = Ethanol extract of sesame seed, ETHSL = Ethanol extract of sesame leaf, - = Absence of the Secondary metabolites, $+=$ Trace presence of Secondary metabolites, $++=$ Presence of Secondary metabolites, $+++=$ Abundance of Secondary metabolites 
Extracts from different plants have been studied to possess insecticidal properties against a wide range of insect pests (Abdullah \& Muhammad, 2004). The study conducted showed promising bio-pesticidal potentials of two plant botanical extracts namely sesame and Trichilia heudelotii against various life stages of the ruthless insect pest Callosobruchus maculatus infesting cowpea grains.

The current study investigated the use of N-hexane and Ethanol extracts of Trichilia heudelotii leaf, sesame leaf and seed. The extracts of the treatment used were mostly effective at an increased rate of 1.5 $\mathrm{ml}$ invariably resulting to the control of $C$. maculatus in cowpea.Sesame and T. heudelotii extracts increased adult mortality, reduced oviposition and larvae emergence rate, constricted the population of the next generation of $C$. maculatus adults fromemerging and also had the lowest cowpea weight loss when compared to untreated ones. Several reports have suggested the bio-insecticidal action of the selected plant extracts. Ahmed et al. (2003) made use of sesame oil and discovered that sesame oil controlled the larvae of Callosobruchus chinensis inside the cotyledons of azuki beans. There was no evaluation of the use of sesame leaves in his study hence the present study showed that $\mathrm{N}$-hexane and ethanol leave extracts of sesame could be considered a plausible control against C. maculatus when used as additives on cowpea grains. In another study, Wheeler andIsman (2001) and LópezOlguín(1998) investigated the use of different plant parts of the genus Trichilia anddiscovered that it has insecticidal and antifeeding effects against some field insects. This, too, was without consideration of the Trichilia species-heudelotii as indicated in this research that the leave extracts of the plant could possibly be used to restrict the life cycle of the bean weevil from further development in grains.

The insecticidal properties of the extracts of Trichilia heudelotii leaf, Sesame leaf and Sesame seed might be connected to the phytochemical constituents such as alkaloids, flavonoids, steroids, terpenoids and tannin. Anilakumaret al (2010) stated that sesame plants contain many phytochemically important compounds like flavonoids, phenolic acids, alkaloids, tannins, saponins, steroids and terpenoids that could restrict the activities of various insect pests. Similarly, it was reported that the genus Trichilia is a good source of different classes of phytochemical compounds with bio-insecticidal potentials in the control of insect pests(Garcia-Gomez et al., 2019; Sengottayan, 2013; Curcino-Vieira et al., 2014). These components may be having the role of biochemical defenses or protectant against $C$. maculatus in cowpea grains.

The antagonistic action of the treatment extracts may be partially attributed to interference in the normal respiration of the insect pest, leading to suffocation
(Schoonhoven, 1978). Other factors other than shortages of oxygen supply may also play its unique role in their mode of action (Shaaya \& Ikan, 1978). Egg mortality has been previously connected to toxic components of plant materials and also to their physical properties which could cause changes in surface tension and also oxygen tension within the insect eggs (Singh et al., 1978).

Al-lawati et al (2002a,b) stated that materials gotten from plants have been traditionally used and accepted by farmers due to their relatively safe usage in protecting and preserving grains from pest attacks. The study relatively showed that there was better maintenance and very low loss of the grain weight of cowpea after having been treated with the botanicals

is advisable for short grain storage because of high degradability and volatility of the plant material (Salako et al., 2008) this is comparatively safer in preserving cowpea grains for a short period as it is intended to be eaten soonthereby leaving off no toxic chemical residues. Plant materials with insecticidal and preservative potentialscould be easily sourced and acquired from local environmentand also suggested as a cheaper, quick and eco-friendly option in preserving food grains such as cowpea for home usage due to the developing fears of using chemical pesticides (Mukanga et al., 2010).

\section{Conclusion}

The use of plant materials as insecticides is increasingly gaining prominence as a sustainable means of pest management in cowpea grains.Previous studies have revealed the negative impacts of chemical insecticides, even the reports of deaths of consumers of cowpea who ingested grains containing lethal dosage of the substance after 24 hours. Biopesticides, on the other hand, poses no deleterious risk to human health, the environment and non-target organisms. The use of sesame (seed and leaf) and Trichilia heudelotii (leaf) $\mathrm{N}$-hexane and ethanol extracts indicated active insecticidal potentials against the notorious insect pestCallosobruchus maculatus whose reputation is known to be extremely destructive, drastically reducing cowpea yield and its market values. The plant extracts added to cowpea grains as alternatives to synthetic insecticides effectively reduced the population of the weevil further disorienting the various life cycle of the insect pest from development in cowpea. The solution presented here could be easily adopted by household users in preventing their grain stock from degradation by the insect pest therefore a recommendation of subsequent research to improve the longevity and persistence of the bioactive compounds of these plant extracts on cowpea is suggested. 


\section{References}

Abdullahi YM, Muhammad S (2004). Assessment of the toxic potentials of some plant powders on survival and development of Callosobruchus maculatus. Afr. J. Biotech3:60-64.

Ahmed KS, Itino T, Ichikawa T (2003). Duration of developmental stages of Callosobruchus chinensis L.(Coleoptera:Bruchidae) on azuki bean and the effects of neem and sesame oils at different stages of theirdevelopment. Pak. J. Biol. Sci. 6: 932-935.

Akyaw MO, Baidoo PK, Mochiah MB. (2014). The effect of time harvest on the damage caused to cowpea by storage beetle, Callosobruchus maculatus (FAB.) (Coleoptera: Bruchidae).Global advancedresearch journal of agricultural science 3(11): 351-355.

Al-Lawati HT, Azam KM, Deadman ML. (2002a). Insecticidal and Repellent Properties of Subtropical Plant Extracts Against Pulse Beetle, Callosobruchus chinensis. Agric. Sci. 7: 37-45.

Al-Lawati HT, Azam KM, Deadman ML (2002b). Potential of Omani Flora as Source of Natural Productsfor Control of Pulse Beetle, Callosobruchus chinensis. Agric. Sci. 7: 59-63.

Anilakumar KR, Pal A, Khanum F, Bawa AS (2010). "Nutritional, medicinal and industrial uses of sesame (Sesamum indicum L.) seeds - An overview." Agriculturae ConspectusScientificus, 75(4): $\quad$ 159-168.

Asante SK, Tamo M, Jackai LEN (2001). Integrated management of cowpea pest using elite cultivars, date of planting and minimum insecticide application. Afr Crops Sci J.9(4):655-665

Asiwe JAN, Belane D, Dakora FD (2009). Evaluation of cowpea breeding lines for nitrogen fixation atARC-Grain Crops Institute, Potchefstroom, South Africa. Abstract, the 16th International Congress on Biological Nitrogen Fixation, Montana, USA, pp 14-19

Boukar O, Fatokun C (2009). Strategies in cowpea breeding. In Zerihun $\mathrm{T}$ (ed) New approaches to plantbreeding of orphan crops in Africa: proceedings of an international conference, 19-21 September 2007,Bern, Switzerland, pp 69-92

Brisibe EA, Adugbo SE, Ekanem U, Brisibe F,Figueira GM (2011). Controlling Bruchid Pests of StoredCowpea Seeds with Dried leaves of Artesmisia annua and Two Other Common Botanicals. Africa Journal ofBiotechnology10(47): 9586-9592.

Coulibaly O, Alene AD, Manyong V, Sanogo D, Abdoulaye T, Chianu J, Fatokun C, et al. (2009). Situation and outlook for cowpea and soybean in sub-Saharan Africa. II Project in West and East Africa.
Curcino-Viera IJ, Silva-Terra W, Dos Santos GM, Braz-Filho R (2014).Secondary metabolites of thegenus Trichilia: contribution to the chemistry of Meliaceae family. American Journal of AnalyticalChemistry 5: 91-121.

Dugje IY, Omoigui LO, Ekeleme F, Kamara AY, Ajeigbe H (2009). Farmers' Guide to Cowpea Production in West Africa. IITA, Ibadan, Nigeria. p20.

FAO (Food and Agriculture Organisation of the United Nations)(2005). The state of food and agriculture. Document prepared for the International Conference on Worlds' state of food. FAO, Rome, Italy.

Garcia-Gomez A, Figueroa-Brito R, Garcia-Serrano LA, Jimenez-Perez A(2019). Trichilia (Meliaceae) plants: an important source of biomolecules with insecticidal properties. Florida Entomologist 101 (3):470-479.

Gwary OM, Hati SS, Dimari GA, Ogugbuaja VO (2012). Pesticide residues in bean samples fromNorth-EasternNigeria. J Sci Technol2(2): 9784.

Harborne JB (1973). Phytochemical Methods: A Guide to Modern Technique of Plant Analysis. Chapman and Hall Ltd

Jackai LEN, Daoust RA (1986). Insect pests of cowpeas. Annu Rev Entomol 31:95-119

Karungi J, Adipala E, Ogenga-Latigo, MW et al (2000). Pest management in cowpea. PartI. Influence of planting time and plant density on cowpea field pest infestation in eastern Uganda. Crop Prot 19:231-36.

Khalequzzaman M, Hussain SMA, Osman GS (2007).Efficacy of edible oils in the control of pulse beetle, Callosobruchus chinensis L. in stored pigeonpea. Univ. j. zool. RajshahiUniv. 26: 89-92.

Langyintuo AS, Lowenberg DJ (2006). Potential regional trade implication of adopting Bt cowpea in) West andCentral Africa. Back Issues Index 9(2): 38-42.

López-Olguín JF (1998). Actividad y modo de acción de productos de Trichilia havanensis Jacq. y Scutellariaalpinasubsp. Javalambrensis (Pau), sobre Leptinotarsa decemlineata (Say) y Spodoptera exigua(Hübner). Tesis de Doctorado. Escuela Técnica Superior de Ingenieros Agrónomos. UniversidadPolitécnica de Madrid. Madrid, España.

Mukanga M., Deedat Y, Mwangata, FS(2010). Toxic effects of five plant extracts against the larger grainborer, Prostephanustruncatus. Afr. J. Agric. Res. 5(24): 3369- 3378.

Mulatu B, Gebremedhin T. (2000). Ovipositiondeterrent and toxic effects of various botanicals on the Adzukibean beetle, Callosobruchuschinensis L. Insect Sci Applica, 20(1):33-38. 
Oyewale RO, Bamaiyi LJ (2013). Management of cowpea insect pests. Sch Acad J Biosci (SAJB) 1(5):217-226.

Rachie KO (1985). Introduction. In: Singh SR, Rachie KO (eds) Cowpea research production and utilization. Wiley, London

Salako EA, Anjorin ST, Garba, CD, Omolohunnu EB. (2008). A review of neem biopesticide utilizationand challenges in Central Northern Nigeria. African Journal of Biotechnology 7(25): 4758-4764.

Schoonhoven AV (1978). The use of vegetable oils to protect stored beans from bruchid attack. J. Econ. Entomol. 71, 254-256.

Sengottayan, S. N. (2013). Physiological and biochemical effect of neem and other Meliaceae plants secondary metabolites against Lepidopteran insects. Frontiers in Physiology 4: 359.

Shaaya E, Ikan R. (1978). The effectiveness of vegetable oils in the control of Callosobruchus maculutus.Institute for Technology and Storage of Agricultural Products, Department of Scientific Publications,Special Publication 216, Bet-Dagan, Israel pp 39.

Shaibu I. (2008). 30 agrochemical products banned in Nigeria after deaths. Vanguard [Internet]. Available from:https://www.organicconsumers.org/news/30agrochemical-productsbanned-nigeria-after-deaths Assessed May 17, 2020

Singh BB (2014). Cowpea: the food legume of the 21st century. Crop Sci Soc Am, Madison

Singh SR, Jackai LEN (1985). Insect pests of cowpeas in Africa: their life cycle, economic importance andpotential for control. Cowpea Res. Prod Util217-231

Singh SR, Luse RA, Leuschrer LK,Nangju D. (1978). Groundnut oil treatment for the control
ofCallosobruchus maculatus (F.) during cowpea storage. J. stored Prod. Res. 14: 77-80.

Sofowora LA (1993). Medicinal plants and traditional medicine in Africa spectrum. Books Ltd. Ibadan, pp 191-289

Strong RG, Partida GJ, Warner DN (1968). Rearing stored product insects for laboratory studies, bean and cowpea weevil. J. Econ.Entomol. 61: 747751.

Timko MP, Ehlers JD, Roberts PA (2007). Cowpea:In Genome Mapping and traditional vegetables inTanzania. Technical Bulletin No. 40. AVRDCThe World Vegetable Center, Shanhua, Taiwan, pp 53.

Togola A, Boukar O, Belko N, Chamarthi SK, Fatokun C, Tamo M,Oigiangbe N (2017). Host plantresistance to insect pest of cowpea (Vigna unguiculate L. Walp): achievements and future prospects. Euphytica, 213(239): 1-16.

Trease, G. E. \& Evans, W. C. (1989). Pharmacognosy. 11 Edition, Bailliere Tindall, London, pp 45-50

Uddin II RO, AwololaGV, Mustapha S, Abdulazeez OH, Ilesanmi OT, Aliyu SA (2020). Novel application of Trichilia heudelotii Planch: effectiveness of different polarity of organic solvents of leaf and stem bark extracts on the control of cowpea beetle. CercetăriAgronomiceîn Moldova53(3): 278-296

Udo IO, Harry GI. (2013). Effect of groundnut oil in protecting stored cowpea; Vigna unguiculata from attack by cowpea weevil, Callosobruchus maculatus. J Biol Agric Health Care 3(1):89-92.

Wakili AM (2013). Economic analysis of cow-pea production in Nigeria. Russian J. of Agric. and Socio-Economic Sci 1(13): 60 - 63.

Wheeler D, Isman M (2001). Antifeedant and toxic activity of Trichilia Americana extract against the larvae of Spodoptera litura. EntomologiaExperimentalis et Applicata, 98: 9-16. 